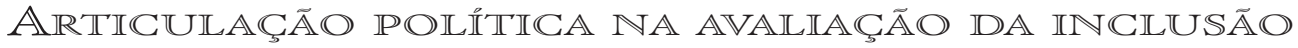
FINANCEIRA PROMIOVIDA PELO BANCO CENTRAL

DO BRASIL

POLITICAL ARTICULATION FOR EVALUATING THE FINANCIAL INCLUSION PROMIOTED BY THE CRENTRAL $\mathbb{B} \mathbb{A N}$ OF $\mathbb{B} \mathbb{R} \mathbb{Z} \mathbb{I}$

\author{
Marcelo Machado Teixeira de Andrade* \\ Eduardo H. Diniz**
}

Restrino

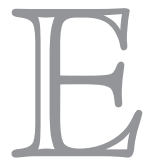

ste artigo analisa a relação entre (i) as atividades de articulação política desenvolvidas para a obtenção dos dados e informações necessários para avaliar uma política pública e (ii) a disponibilidade (ou indisponibilidade) desses dados e informações. A política em foco foi a de inclusão financeira liderada pelo Banco Central do Brasil (BC) no período de 2009 a 2012, tendo-se utilizado a abordagem metodológica do estudo de caso. Descreveram-se as principais iniciativas de inclusão financeira promovidas pelo BC no período, assim como as atividades de articulação política motivadas, direta ou indiretamente, para a obtenção dos referidos dados e informações. Concluiu-se que tais atividades contribuíram destacadamente na obtenção desses dados e informações.

Palavras-chave: Articulação política. Avaliação de políticas públicas. Inclusão financeira. Banco Central do Brasil.

Abstreact

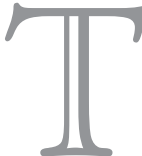

his article analyzes the relationship between (i) political articulation activities created to obtain data and information necessary to evaluate a public policy and (ii) the availability (or unavailability) of such data and information. We studied the financial inclusion policy conducted by the Central Bank of Brazil (BC) from 2009 to 2012 as a case study. The main financial inclusion initiatives related to this policy and promoted by BC in the period are described, as well as the political articulation needed, directly or indirectly, to obtain such data and information. The article concludes that political articulation activities contribute significantly to obtain data and information to evaluate a public policy.

Keywords: Political articulation. Evaluation of public policies. Financial inclusion. Central Bank of Brazil.

\footnotetext{
* Doutor em Administração pela Faculdade de Economia, Administração e Contabilidade da Universidade de São Paulo. Vinculado ao Banco do Brasil. E-mail: Marcelo.andrade@bcb.gov.br

**Doutor em Administração de Empresas com ênfase em Administração da Informação pela EAESP-FGV. Professor da EAESP/FGV. E-mail: eduardo.diniz@fgv.br
} 


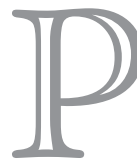

ara avaliar uma política pública são necessários, entre outros recursos, dados e informações. A despeito de que esses sejam imprescindíveis para a avaliação, o processo de obtê-los é um assunto pouco tratado na literatura especializada em administração pública. Quando há menção a tais dados e informações, geralmente faz-se problematizando pouco sua obtenção. É como se aí não existissem problemas, como se sua obtenção fosse automática ("quero isso" igual a "tenho isso"). Esse automatismo só aconteceria se todos os dados e informações necessários à avaliação estivessem prontos e plenamente acessíveis ao avaliador no momento da avaliação. Situações assim, de disponibilidade plena e prévia, configuram-se mais como exceção do que como regra. A regra é o esforço de coleta. As dificuldades embutidas nesse esforço podem não ser pequenas, e a ausência de um dado ou informação importante pode fragilizar ou mesmo tornar inútil a avaliação.

Em se tratando de um processo que é técnico, operacionalizar a avaliação, do ponto de vista dos dados e informações e dos demais aspectos, exige capacidade técnica. Mas o processo é político também, porque a administração pública não é uma ilha técnico-burocrática isolada dos aspectos políticos (FARAH, 2011; PACHECO, 2011; WEISS, 1999; KINGDON, 1995b; SABATIER, 1991; REIS, 1989; LINDBLOM, 1981), em que pesem as tentativas de insulamento burocrático (NUNES, 2003). Daí a necessidade da articulação política, também para superar as dificuldades inerentes à viabilização da avaliação. A discussão "técnica e política" (às vezes, técnica versus política) é recorrente na literatura de políticas públicas. Tal discussão costuma dar-se em um nível macro, em abordagens de escopo amplo sobre políticas públicas ou administração pública. Os conceitos derivados desse referencial teórico macro, assim como de outras fontes indiretas, mais aqueles diretamente referentes à avaliação de políticas públicas, foram aplicados para analisar, em um caso concreto, o processo de obtenção dos dados e informações para a avaliação de uma política pública, com ênfase nos aspectos de articulação política.

O problema de pesquisa anteriormente delineado foi estudado no contexto da política de inclusão financeira liderada pelo Banco Central do Brasil (BC). A questão de pesquisa principal que norteou o trabalho foi a seguinte: qual é a relação entre (i) as atividades de articulação política desenvolvidas para a obtenção dos dados e informações necessários para avaliar a política pública e (ii) a disponibilidade (ou indisponibilidade) desses dados e informações? Como condição para elucidar a questão principal, formulou-se ainda a seguinte questão: em função da definição adotada pelo BC do que seja inclusão financeira, quais são os principais aspectos da política pública que precisariam ser avaliados?

Para os propósitos deste artigo, a referida "articulação política" não diz respeito à política partidária, mas às noções de política no sentido de politics e conceitos associados, como articulação, cooperação e coordenação de atores, conforme apresentados no referencial teórico. Sobre dados e informações, cuja distinção tem muito a ver com objetividade-subjetividade, vale notar que "Um mesmo dado pode gerar informações diferentes, dependendo da interpretação. Seria um erro considerar a informação como algo completamente objetivo" (ANDRADE, 2008, p. 21). Se dados e informações não são a mesma coisa - há vasta literatura a respeito -, distingui-los não faz parte do escopo deste artigo.

Além desta introdução, compõem o artigo cinco outras seções, a saber: referencial teórico, metodologia, descrição do caso, análise do caso e conclusões.

\section{Referernciall teórico}

Em termos de macroinserção, este artigo insere-se no campo teórico das políticas públicas, com ênfase no processo de avaliação. A inclusão financeira, que é a política pública em estudo, será apresentada em subseção à parte deste referencial teórico. 
Poliricicas priblicas e avaliaçăo

De acordo com Secchi (2010), não há uma definição consensual de política pública na literatura especializada. Em linha semelhante, Souza (2006, p. 24) advoga que "não existe uma única, nem melhor definição sobre o que seja uma política pública". Essa autora pondera que "definições de políticas públicas, mesmo as minimalistas, guiam o nosso olhar para o locus onde os embates em torno de interesses, preferências e ideias se desenvolvem, isto é, os governos" (SOUZA, 2006, p. 25). Sem desvalorizar o papel dos atores não estatais - que podem estar ativamente presentes em todas as etapas do processo -, entendemos que uma política pública, para poder ser considerada como tal, deve emanar do poder público (poder instituído), que tem força legal para impor decisões de caráter público. Em sintonia com esse entendimento e baseada em Howlett, Ramesh e Perl (2013) e Dye (1992), a definição de política pública adotada neste artigo é: o que o governo escolhe, intencionalmente, fazer ou não fazer, como resultado de um processo técnico-político que busca compatibilizar objetivos e meios entre atores sociais com restrições.

No parágrafo anterior, mencionou-se "processo" e "fases" de uma política pública. Trata-se de uma das abordagens de análise de políticas públicas recorrentemente encontrada na literatura especializada, conhecida como ciclo da política (policy cicle). Essa abordagem enfatiza os conceitos de ciclo e processo, enxergando a política pública como um ciclo deliberativo formado por vários estágios ou fases, em um processo dinâmico e de aprendizagem para a resolução de um problema público ${ }^{1}$ (SOUZA, 2006; FREY, 2000; THEODOULOU, 1995). Frey (2000), procurando sintetizar as propostas de divisões do ciclo da política pública, postula que as seguintes fases seriam comuns às diversas classificações existentes: formulação, implementação e controle dos impactos das políticas. A última fase, de "controle", é mais comumente nomeada como de avaliação (evaluation), assim como é comum que a primeira fase, precedendo à formulação da política, seja a de definição de agenda (agenda setting), como propõe Souza (2006). Em qualquer caso, conforme a literatura mais contemporânea sobre o assunto, o ciclo da política não é visto como uma sequência linear ou rígida.

Para os propósitos deste artigo, destaca-se a fase de avaliação. De acordo com Arretche (1998), avaliar é primordialmente atribuir um valor, uma medida de aprovação ou desaprovação a uma política ou programa público particular. Mas como observam Cohen e Franco (1992, p. 109), "nem todas as avaliações são iguais", podendo estabelecer-se diferenças entre elas segundo diferentes critérios. Alguns dos critérios mais comumente encontrados na literatura especializada, não mutuamente excludentes, são o momento em que se realiza, quem faz e o que se avalia, ou com que objetivos. Esse último critério (o que/por que se avalia) gera uma multiplicidade de opções: avaliar para aprimorar uma política ou programa em curso (formativa) ou para tirar uma conclusão de uma política ou programa concluído (somativa); avaliar para prestar contas à sociedade e responsabilizar os agentes estatais (accountability); avaliar eficiência, eficácia ou efetividade, produtos (outputs) ou impactos (outcomes), processos ou resultados etc.

Jannuzzi (2011, p. 260) distingue a avaliação enquanto etapa do ciclo (que equivaleria à avaliação somativa) das "atividades de monitoramento e avaliação, que se realizam mediante os sistemas de indicadores e as pesquisas de avaliação, instrumentos investigativos que podem ser empregados a qualquer momento do ciclo". A propósito, Rossi et al. (2004) entendem que a avaliação deve acompanhar cada etapa do ciclo de vida da política ou programa em foco, com ênfases diferentes em cada fase.

Faria (2005, p. 98) aponta, na abordagem que ele considera mais canônica do processo de avaliação de políticas públicas, "um viés francamente normativo e/ou uma priorização dos aspectos mais técnicos da avaliação das políticas públicas". Tachando

1 Sobre "problema público": "Um problema existe quando o status quo é considerado inadequado e quando existe a expectativa do alcance de uma situação melhor. [...] um problema só se torna público quando os atores políticos intersubjetivamente o consideram problema (situação inadequada) e público (relevante para a coletividade)" (SECCHI, 2010, p. 7-8). 
essa abordagem de "tecnicista", procura ressaltar o caráter, a seu ver, eminentemente político desse tipo de avaliação. O autor associa esse caráter político ao uso que se faz da avaliação, destacando "a virtual subordinação do uso gerencial da avaliação e de sua suposta capacidade de encerrar, reiniciar ou revitalizar o ciclo das políticas às injunções políticas mais abrangentes e às estratégias e interesses dos tomadores de decisão e dos demais envolvidos" (FARIA, 2005, p. 98). Na mesma linha, Pinto (1986, p. 89) observa que

Os decisores [públicos], com sua equipe de assessoria, constituem o segmento, por excelência, em condições potenciais para se apropriarem dos achados avaliativos. Ao decidirem sobre a pertinência de mudanças, são, contudo, orientados por critérios políticos, e não propriamente pelas evidências ou descobertas científicas. São dirigidos pela lógica dos fatos políticos, necessitando resolver problemas sob pressão, e com agenda apertada.

Weiss (1999), analisando a interface entre a avaliação e a tomada de decisão no âmbito das políticas públicas, também enfatiza a importância dos propósitos políticos da avaliação. Para essa autora, as expectativas dos avaliadores em relação ao uso da avaliação sempre tiveram um matiz racional, o que frequentemente acarreta desapontamento, quando percebem "que os elaboradores de políticas muitas vezes parecem ignorar os resultados da avaliação, encampando políticas que já haviam escolhido por outras razões" (WEISS, 1999, p. 470). Segundo Weiss, é preciso entender que a elaboração de políticas é a arena de embate das pressões conflitantes da sociedade.

Na elaboração de políticas, o embate é chamado de "política" [politics]. Múltiplos interesses colidem e buscam vantagens. A avaliação pode ajudar os diferentes grupos - e a sociedade como um todo - a entender as prováveis consequências de diferentes escolhas e os modos pelos quais compromissos ou acomodações servirão seus interesses. Mas a avaliação ela própria não determina a direção para o sistema como um todo (WEISS, 1999, p. 477).

O impacto da avaliação nas políticas públicas ocorreria mais a longo prazo e, em qualquer caso, mediado por variáveis que são, em grande medida, políticas. Políticas no mencionado sentido de politics, que ocorre também no nível organizacional. Weiss (1999, p. 471) chega a falar de uma "endêmica prioridade da 'política' em todas as organizações", que, ao lado da complexidade dos sistemas de tomada de decisão, seria causa da frustração associada à avaliação. Vale observar que a autora não aborda a influência das variáveis políticas como que lamentando tal influência. Reconhece-a, no contexto democrático, e recomenda que seja reconhecida - e respeitada - pelos avaliadores. "A política é o sistema que as democracias têm para reconciliar interesses divergentes e alcançar acomodações que satisfazem a maior parte das pessoas a maior parte do tempo" (WEISS, 1999, p. 483). Em linha semelhante, Silva e Melo (2000, p. 12-13) observam que "A estratégia tecnocrática de se eliminar ou insular a política pública do jogo político mais amplo tem efetivamente se mostrado irrealista e pouco democrática".

Além dos trabalhos que versam diretamente sobre avaliação de políticas públicas, anteriormente citados, o referencial teórico que suportou a análise do presente caso contou com uma bibliografia indireta, relatada a seguir, que enriqueceu a análise do tema em foco.

O'Toole Junior (2010), discutindo as relações interorganizacionais no processo de implementação, enfatiza a importância da cooperação entre órgãos públicos, entre estes e organizações privadas e também entre departamentos de um mesmo órgão ou entidade pública. Entre outras razões que explicariam o acréscimo de atores dentro do processo de implementação, o autor menciona que "coalizões" tendem a deter críticas e aumentar as chances de sucesso da implementação. Tais coalizões devem ser construídas: não se pode assumir que existe apoio, mas trabalhar para obtê-lo. "Tipicamente não podem contar com os arranjos institucionais hierárquicos para solidificar acordos - além de sua própria unidade formal, de qualquer maneira" (O'TOOLE JUNIOR, 2010, p. 236). 
Brinkerhoff (1996), comentando a questão da coordenação na implementação de políticas, observa que a estrutura, formal ou informal, criada pelas múltiplas ligações entre os atores envolvidos na implementação forma redes de organizações. Essas redes, defende o autor, precisam ser devidamente coordenadas. Uma forma de fazê-lo seria combinando dois tipos de estrutura, que ele chama de "mercado" e "hierarquia". Característica do primeiro tipo seria deixar pessoas e grupos mais livres, enquanto o segundo tipo se caracterizaria por apoiar-se mais em coordenação central e hierárquica. Definir "quanto" adotar de cada tipo seria uma decisão a ser tomada em cada caso.

Souza (2006) sintetiza uma série de modelos de formulação e análise de políticas públicas, um dos quais é o de arenas sociais. Por esse modelo, a política pública seria iniciativa dos chamados empreendedores políticos ou de políticas públicas - conceito extensamente tratado por Kingdon (1995a).

\begin{abstract}
Esses empreendedores constituem a policy community, comunidades de especialistas, pessoas que estão dispostas a investir recursos variados esperando um retorno futuro, dado por uma política pública que favoreça suas demandas. [...] Esses empreendedores podem constituir, e em geral constituem, redes sociais. Redes envolvem contatos, vínculos e conexões que relacionam os agentes entre si e não se reduzem às propriedades dos agentes individuais (SOUZA, 2006, p. 32).
\end{abstract}

Em um nível macro de análise, Pacheco (2011), Farah (2011), Reis (1989) e Lindblom (1981) discorrem sobre a polaridade "administração" (ou burocracia, ou técnica) e "política". Para Lindblom (1981, p. 20), "o papel da análise [técnica] no processo de decisão política é inevitavelmente limitado (e exige a participação da 'política')". Pacheco (2011, p. 25), refletindo sobre a nomeação para cargos de direção na administração pública, afirma haver diversidade de critérios, mas pondera que, nos debates, em geral essa diferenciação acaba sendo esquecida "em prol de uma visão ainda muito marcada pelas origens do paradigma burocrático da separação entre política e administração. Como se isso fosse possível, desejável e a única forma de organizar o Estado para que ele tenha qualidade". Em linha semelhante, Farah (2011) mostra como a administração pública, tanto nos Estados Unidos como no Brasil, esteve por muito tempo dissociada do âmbito da análise e da formulação de políticas públicas, ancorada no ideal weberiano e nos princípios da administração científica, que separavam administração e política em nome da neutralidade e da racionalidade. Farah (2011, p. 820) observa que, "nas últimas décadas, o 'público' da administração pública foi redefinido, ampliando suas fronteiras para além do Estado". Nesse sentido, para Rabell (apud FARAH, 2011), a disciplina administração pública não poderia mais restringir-se ao estudo das questões ligadas à burocracia governamental, uma vez que as políticas públicas dependem, já há algumas décadas, de uma rede de atores sociais, da coordenação de diversas jurisdições e da articulação de atores governamentais e não governamentais.

Refletindo sobre o movimento de progressiva incorporação à administração pública dos assuntos antes exclusivos dos formuladores de políticas públicas (os políticos), Farah (2011, p. 822) observa que,

segundo os críticos da abordagem mainstream da análise de políticas públicas, esta se consolidou reintroduzindo a separação entre política e administração no interior mesmo da análise de políticas públicas. Segundo tais críticos (DURNING, 1999; LYNN, 1999), a abordagem dominante no campo é uma abordagem que se baseia no "sonho" positivista da objetividade e da racionalidade, que supõe que o fato objetivo é passível de apreensão pelo analista, por meio de métodos científicos neutros, e que o conhecimento gerado a partir destes métodos (quantitativos) será útil à decisão (esta sim, política) tomada pelos tomadores de decisão e policy makers.

Essa observação de Farah (2011) acerca da reintrodução da separação entre política e administração por um segmento importante de autores evidencia que, nas diversas abordagens da administração pública, a ênfase nos aspectos técnicos, econômicos e políticos também é diversa. 
A propósito da polaridade administração e política, Reis (1989, p. 1) pondera que,

se já para Weber a distinção entre burocratas e políticos só valia enquanto delimitadora de tipos ideais, com mais razão isso se aplica ao mundo de hoje, onde a confluência de papéis burocráticos e políticos se torna tão acentuada a ponto de sugerir a alguns [Aberbach, Rockman e Putnam, 1981, a seguir citados] a conveniência de raciocinar em termos de um novo tipo "híbrido", derivado precisamente da fusão de características dos dois tipos.

Aberbach, Rockman e Putnam (1981), a partir de um amplo estudo comparativo, delinearam quatro perfis típicos (ou imagens, na expressão deles) para retratar a interação de características de burocratas e de políticos nas atividades de elaboração de políticas. O primeiro tipo estaria bastante próximo do estereótipo weberiano, pelo qual caberia ao político definir a política e ao burocrata administrá-la. O último tipo seria o "híbrido puro", que fundiria completamente traços burocráticos e políticos. Para a referida autora, a fusão completa não seria uma realidade desejável: "idealmente, burocratas asseguram estabilidade e políticos garantem inovação, criatividade à formulação de políticas públicas. Conjunturas particulares podem eventualmente tornar uns ou outros mais proeminentes, mas a diversidade de estilos é persistente e vantajosa" (REIS, 1989, p. 4). Igualmente, Aberbach, Rockman e Putnam (1981) concluem que, a despeito da tendência à fusão de papéis, as especificidades que burocratas e políticos aportam à condução das políticas públicas continuam relevantes.

Inclirsaro financeiral - conceitos e aspectos históricos

Um país "financeiramente inclusivo" pode ser entendido como aquele cuja população adulta em geral tem amplo acesso a produtos e serviços financeiros (que são aqueles relacionados a pagamentos, crédito, poupança/investimento ou gerenciamento de risco), sem barreiras de preço ou de outro tipo (DEMIRGUC-KUNT; KLAPPER, 2012). Para esses autores, "sem um sistema financeiro inclusivo, os mais pobres contam apenas com suas limitadas economias para investir em educação ou tornarem-se empreendedores, e as pequenas empresas ficam constrangidas a seus limitados ganhos para aproveitar oportunidades promissoras de crescimento" (DEMIRGUC-KUNT; KLAPPER, 2012, p. 1). Como pondera Mas (2009, p. 57), "as finanças são essenciais para ajudar as pessoas a escaparem de uma existência da-mão-para-a-boca". Mais especificamente,

Um melhor acesso a serviços financeiros amplos pode ajudar as pessoas de baixa renda a reduzir seu isolamento econômico, a construir ativos financeiros e a aumentar suas oportunidades econômicas de três formas: (1) fortalecendo sua capacidade de receber e fazer pagamentos que não sejam em dinheiro; (2) provendo-Ihes acesso à gama completa de produtos financeiros; e (3) ligando-as às redes e à informação necessária para a participação plena na economia formal (WEISSBOURD, 2002, p. 3).

A propósito do acesso à gama completa de produtos financeiros mencionado, tenha-se em conta uma ponderação do autor. Discorrendo sobre possíveis causas da falha do mercado em prover amplo acesso financeiro à população de baixa renda, Weissbourd (2002) considera que alguns estereótipos arraigados inibem a inovação no setor financeiro. Um dos estereótipos - ou mitos - seria que as pessoas de baixa renda não querem poupar ou investir. Esse mito funcionaria como um desestímulo a que o setor financeiro oferecesse produtos de poupança ou investimento à população mais pobre (adaptados às características do segmento ou subsegmentos, como é normal na oferta de produtos ou serviços de quaisquer tipos).

Tendo em vista o que seja um sistema financeiro inclusivo - ou, posto de outra forma, um país financeiramente inclusivo -, pode-se definir inclusão financeira como "prover acesso a produtos e serviços financeiros adequados às necessidades da população" (BC, 2010, p. 17). Essa foi a definição adotada pelo BC em 2009. Conforme exposto no primeiro Relatório de Inclusão Financeira do Banco Central (BC, 2010), 
uma adequada inclusão financeira colabora na redução da pobreza por meio de duas contribuições mutuamente relacionadas: o desenvolvimento da indústria financeira, que fomenta o crescimento econômico, e o aumento da qualidade de vida da população, ao ver atendidas suas demandas por serviços financeiros. Nesse contexto, e tendo em conta o diagnóstico de que há carências na oferta de serviços financeiros para a população de baixa renda e precariedade na utilização dos instrumentos financeiros por esse público, o BC resolveu ampliar a definição de inclusão financeira, de modo a evidenciar a necessidade de efetiva utilização dos serviços. A definição ficou assim: "processo de efetivo acesso e uso pela população de serviços financeiros adequados às suas necessidades, contribuindo com sua qualidade de vida" (BC, 2010, p. 18).

Para que a inclusão seja efetiva, é preciso atuar sobre a oferta e sobre a demanda de serviços financeiros. No tocante à demanda, o BC reconhece a necessidade de "conferir atenção à educação financeira e à proteção aos usuários, de forma a garantir que a utilização de serviços financeiros seja sustentável e benéfica a todos" (BC, 2011, p. 16). Diniz, Birochi e Pozzebon (2012), em um estudo de caso sobre inclusão financeira em um município da região amazônica, concluem que o acesso a recursos financeiros, para ser efetivo em termos de desenvolvimento, deve ser acompanhado de outros mecanismos de inclusão, nomeadamente a educação financeira.

Sobre a qualidade de vida, que faz parte da definição adotada pelo BC, tenha-se em conta que o conceito de pobreza não deve limitar-se à (falta de) renda. Por exemplo, poder pagar uma conta ou fazer um depósito de poupança sem ter que deslocar-se para outro município amplia a liberdade do cidadão para dispor do seu tempo. Nesse sentido, reduz sua pobreza, entendida, sob uma ótica ampliada e alternativa, como restrição da liberdade (SEN, 2000).

O conceito de inclusão financeira, que é relativamente recente, foi antecedido pelo de microfinanças, e este, por sua vez, pelo de microcrédito (BC, 2010). Microfinanças são "serviços financeiros em pequenos valores, que usam metodologias e estratégias especializadas, comprovadamente mais adequadas para os clientes que normalmente são excluídos do sistema financeiro justamente por serem pobres" (DIAS; SELTZER, 2009, p. 246). O microcrédito - crédito em pequena escala - é um dos produtos microfinanceiros.

\begin{abstract}
No início, acreditava-se que a expansão da quantidade de empréstimos [microcrédito] era a melhor forma de apoiar a economia dos setores mais desassistidos da população. Entretanto, hoje se percebe que essa expansão precisa ser acompanhada de outros serviços que permitam àquelas pessoas administrar melhor seus ganhos e ativos, implementando o manejo de suas economias e mitigando os riscos (SOARES; MELO SOBRINHO, 2008, p. 14).
\end{abstract}

Considerando a evolução dos conceitos (microcrédito, microfinanças, inclusão financeira), compreende-se que, quando praticava-se microfinanças em geral ou microcrédito em particular, promovia-se a inclusão financeira, mesmo que a expressão ou o conceito não fossem conhecidos. É o caso de uma experiência pioneira do que hoje entendemos por microcrédito. Iniciada em 1973, no Recife, a União Nordestina de Assistência a Pequenas Organizações (UNO) associou crédito, assistência técnica e capacitação com vistas a melhorar as condições econômicas e sociais de pessoas de baixa renda (FELTRIM; VENTURA; DODL, 2009). Outro exemplo de iniciativa de inclusão financeira, muito antes do advento dessa expressão, é a criação, em 1902, da primeira cooperativa de crédito do Brasil, em Nova Petrópolis/RS. O contexto de sua criação eram as dificuldades de financiamento e poupança vividas por produtores de comunidades rurais isoladas (FREITAS; DAMIAN; GIUSTI, 2009). Esses dois exemplos têm em comum, além de constituírem marcos históricos, a origem e o desenvolvimento essencialmente privados - característica, aliás, do desenvolvimento inicial das microfinanças no Brasil (FELTRIM; VENTURA; DODL, 2009). Foram iniciativas de inclusão financeira, mas dissociadas de políticas públicas de inclusão financeira (recorde-se o conceito adotado de política pública, que pressupõe uma decisão estatal de fazer ou não fazer e a liderança do poder público na elaboração da política). Em anos mais recentes, não faltam exemplos de ações de inclusão financeira no âmbito de políticas públicas. Na esfera federal, entre outros, podem citar-se: o projeto de expansão do 
microcrédito conduzido pelo Conselho da Comunidade Solidária, instituído em 1995, e o programa de microcrédito Crediamigo, do Banco do Nordeste do Brasil, o maior do gênero na América do Sul, lançado em 1998. São apenas exemplos, mas que dão ideia da diversidade de iniciativas e atores. A atuação do BC será relatada em seção à parte (descrição do caso).

MIetodologial

O problema de pesquisa foi abordado de forma qualitativa, tendo-se optado pelo estudo de caso como estratégia para responder às questões de pesquisa, explicitadas na introdução deste artigo. Em linhas gerais, o fenômeno retratado na presente pesquisa é o processo de obtenção dos dados e informações necessários à avaliação de políticas públicas pelo órgão público que promove essa política (o $B C$ ), com destaque para a importância da articulação política. Quer dizer, a unidade de análise é um processo levado a cabo dentro de uma instituição pública. O caso objeto do presente estudo pode ser considerado, conforme categorização de Yin (2005), revelador, pois trouxe à luz processos internos ocorridos em uma instituição pública complexa. Hammersley, Gomm e Foster (2009) advogam que uma das justificativas do estudo de caso, na vertente caso único, é precisamente a revelação de processos causais em sistemas de baixa visibilidade externa.

A delimitação temporal do caso é o período de 2009 a 2012. O início do período (2009) corresponde ao ano em que o BC fez da inclusão financeira projeto estratégico da instituição - o que ensejou, entre outras ações, um intenso esforço de coleta, organização e análise de dados sobre o setor microfinanceiro brasileiro -, e o final do período (2012) explica-se pelo momento da pesquisa, iniciada em 2012 e encerrada em julho de 2013. Menções a fatos anteriores a 2009 ou a atores externos ao BC devem ser consideradas contextuais.

A pesquisa contou com dados primários e secundários. Os dados secundários foram obtidos do livro Microfinanças: o papel do Banco Central do Brasil e a importância do cooperativismo de crédito (SOARES; MELO SOBRINHO, 2008) - editado pelo BC. As fontes dos dados primários foram os Relatórios de Inclusão Financeira n. 1 e n. 2 do BC (2010-2011), os Anais do 10, $2^{\circ}$ e $3^{\circ}$ Fórum Banco Central sobre Inclusão Financeira (2009-2011), o Plano de Ação para Fortalecimento do Ambiente Institucional (2012), as Resoluções do Conselho Monetário Nacional (CMN) e os planos dos projetos Inclusão Financeira I (2009) e II (2011) do BC. Com exceção dos dois últimos documentos (referentes aos projetos), que são internos, os demais são públicos, estando disponíveis no site do BC (www.bcb.gov.br). Fez-se também pesquisa de campo, com a utilização de entrevistas semiestruturadas, que ocorreram entre novembro de 2012 e junho de 2013, tendo sido entrevistadas Elvira Ventura e Paula Buzolin, respectivamente chefe do Departamento de Educação Financeira do BC e assessora plena desse mesmo departamento (posições de junho de 2013). Acresça-se que a Sra. Elvira Ventura foi gerente dos projetos estratégicos Inclusão Financeira I e II (2009 a 2013), e a Sra. Paula Buzolin fez parte das equipes desses mesmos projetos. O registro das entrevistas foi feito por meio de anotações, uma vez que não houve autorização para gravação.

\section{Descrição do cass: o Banco Cerntrall e at inclusắ firnarceir}

No referencial teórico, subseção "Inclusão financeira - conceitos e aspectos históricos", observou-se que a criação da primeira cooperativa de crédito no Brasil, em 1902, significou, na prática, uma iniciativa de inclusão financeira (recorde-se a evolução conceitual: microcrédito, microfinanças, inclusão financeira). De modo semelhante, pode-se falar em iniciativas de inclusão financeira no âmbito do BC praticamente desde a sua criação, em 1964. Por exemplo, em 1965, por intermédio 
da Resolução $\mathrm{n} .11$, foram dados os primeiros passos reguladores das cooperativas de crédito, transformadas em instituições financeiras no ano anterior ${ }^{2}$. Contudo, de forma mais intensa, os esforços do BC em prol da inclusão financeira (ou, mais restritamente, do microcrédito ou das microfinanças) situam-se a partir de meados da década de 1990.

Em 1999, o BC implementou ações regulamentares importantes referentes a três dos pilares da política de inclusão financeira: o cooperativismo de crédito (pela Resolução n. 2.608), o microcrédito (pela Resolução n. 2.627) e os correspondentes (pela Resolução n. 2.640). Da Resolução n. 2.608, destacam-se o incentivo à estruturação das cooperativas de crédito em sistemas integrados, supervisionados por centrais de crédito (que reduzem os riscos inerentes ao negócio), e o aumento do público-alvo, mediante critérios mais flexíveis de admissão de associados (o que amplia economias de escala). Para a edição dessa resolução, cabe ressaltar a contribuição de um grupo de trabalho composto por representantes do setor, parlamentares e técnicos do BC. A evolução normativa que se seguiu à referida resolução contou com efetiva participação do setor cooperativista de crédito, interessado no processo e nele envolvido pelo $\mathrm{BC}$ (envolvimento que não se restringiu à participação de técnicos da instituição, mas de dirigentes também, em ações tipicamente políticas, de articulação, negociação e mediação de disputas). A Resolução n. 2.627 regulamentou as Sociedades de Crédito ao Microempreendedor (que são agentes de microfinanças), convertidas em Sociedades de Crédito ao Microempreendedor e à Empresa de Pequeno Porte pela Resolução n. 3.567, de 2008. E a Resolução n. 2.640, referente aos correspondentes, ampliou o escopo desses agentes, aumentando o rol tanto de serviços como de contratantes permitidos.

Os correspondentes, estabelecidos e regulamentados inicialmente pela Circular n. 220 do BC, de 1973, são prestadores de serviços contratados por instituições financeiras, não podendo ter como atividade principal a de correspondente. Visam ao fornecimento de produtos e serviços de responsabilidade da instituição contratante, tais como: receber e encaminhar propostas de abertura de contas de depósitos à vista e de poupança, bem como de emissão de cartão de crédito; movimentar contas; realizar recebimentos e pagamentos de contas de prestação de serviços (como água, luz e telefone); encaminhar pedidos de empréstimo etc. Exemplos comuns de correspondentes são casas lotéricas, supermercados e farmácias. Em grande parte como fruto da expansão dos correspondentes, desde 2002 não existe nenhum município brasileiro sem acesso a serviços financeiros ${ }^{3}$.

Outra medida importante adotada pelo BC em prol da inclusão financeira foram as contas, corrente e de poupança, simplificadas. Criadas pelas Resoluções n. 3.104 e n. 3.113 , respectivamente, ambas de 2003 , caracterizam-se pela maior facilidade de abertura e isenção de tarifas. Os correspondentes e as contas simplificadas são os dois principais canais de pagamento de benefícios do Programa Bolsa Família, o que mostra a importância desses instrumentos para a população mais pobre 4 .

Principalmente a partir do final da década de 1990, o BC promove ou participa de estudos conjuntos, reuniões e seminários sobre temas relacionados à inclusão financeira. Entre 2002 e 2008, em parceria com o Serviço Brasileiro de Apoio às Micro e Pequenas Empresas (Sebrae), o BC realizou nove seminários nacionais de grande porte para a divulgação das microfinanças. Em 2003, os eventos, focados

2 Todas as resoluções citadas neste artigo são normas emitidas pelo CMN, órgão deliberativo máximo do Sistema Financeiro Nacional (SFN). As resoluções do CMN propostas pelo BC são elaboradas por essa autarquia e remetidas àquele órgão para aprovação e publicação.

3 A despeito dos resultados francamente positivos alcançados com o desenvolvimento dos correspondentes, cabe mencionar as ponderações de Diniz e Gonzalez (2013). Segundo eles, o modelo de correspondente adotado no Brasil, desenhado sobretudo para ampliar a rede de distribuição de benefícios sociais e para o recebimento de contas, parece estar chegando ao seu limite.

4 De acordo com dados de setembro de 2010, do Ministério do Desenvolvimento Social e Combate à Fome, o Programa Bolsa Família transferiu recursos para aproximadamente 13 milhões de famílias por mês. Das famílias beneficiárias do programa, 7,8 milhões receberam os benefícios por meio de correspondentes e 1,8 milhões por meio de crédito em conta simplificada (BC, 2010). 
inicialmente no microcrédito, foram reformulados de modo a conter também outros temas ligados ao segmento microfinanceiro, como cooperativismo de crédito e moedas sociais. Paralelamente aos seminários, o BC realizou também pequenos eventos com fins diversos, que promoveram, de uma forma ou de outra, a inclusão financeira, como reuniões com operadores de microfinanças e encontros para formação de grupos de trabalho. Muitos desses eventos menores deram-se no âmbito do projeto estratégico Governança Cooperativa, cujas atividades desenvolveram-se entre 2006 e 2009, que objetivou definir e disseminar boas práticas de governança para cooperativas de crédito. Os próprios seminários nacionais ensejaram a realização de eventos paralelos menores, que serviram como fóruns informais de discussão da indústria microfinanceira.

Conforme declarado nas entrevistas, depois da edição de 2008 dos citados seminários, não havia previsão de novos encontros desse gênero. Ao mesmo tempo, existia a percepção, dentro do $\mathrm{BC}$, de que as microfinanças não se desenvolviam a contento no Brasil (vale notar que, desde 2003, as microfinanças e a inclusão financeira mereceram atenção especial de diversos setores do governo federal). Nesse contexto, 0 então Diretor de Normas e Organização do Sistema Financeiro, Sr. Alexandre Tombini, incentivou a equipe responsável por esses seminários a prosseguir com a iniciativa, iniciando um novo ciclo, não de divulgação apenas, mas de diagnóstico do setor. Com o objetivo de preparar esse novo ciclo, as Sras. Elvira Ventura e Alessandra Dodl prepararam uma nota técnica sobre microfinanças, que embasou o projeto estratégico Inclusão Financeira I - Diagnóstico e Articulação. Esse projeto, instituído em 2009, durou até 2011, seguido, sem solução de continuidade, pelo projeto estratégico Inclusão Financeira II - Mapeamento e Regulação, previsto para durar até 2013 (para os efeitos deste artigo, exceto quando se faça referência específica, os projetos I e II serão tratados como se fossem um único projeto). O objetivo inicial foi diagnosticar o setor microfinanceiro no Brasil e articular os diferentes atores envolvidos no processo de inclusão financeira. Com vistas à articulação e coordenação com outros órgãos e entidades, destacam-se os Fóruns Banco Central sobre Inclusão Financeira, eventos de grande porte realizados em parceria com o Sebrae (quatro, entre 2009 e 2012, com periodicidade anual), e as reuniões e encontros que os precederam.

As reuniões que antecederam o primeiro Fórum serviram para interlocução inicial e estabelecimento de parcerias e os encontros prévios (reuniões de maior envergadura), para aprimoramento da abordagem metodológica que seria utilizada e consolidação de parcerias. Nos encontros, minuciosamente preparados e executados, a equipe do projeto Inclusão Financeira apresentou o projeto, os eixos temáticos e a metodologia de grupos de trabalho. Essa mesma equipe ficou responsável pela análise das críticas, pelas alterações decorrentes delas, pelo aproveitamento das sugestões apresentadas pelos grupos para a metodologia e pela consolidação das questões a serem debatidas no Fórum. Organizaram-se três encontros. O primeiro, com atores do governo, contou com 10 participantes dos seguintes órgãos: o Banco Nacional de Desenvolvimento Econômico e Social (BNDES) e os ministérios do Trabalho e Emprego, do Desenvolvimento Agrário, do Desenvolvimento Social e Combate à Fome e da Cultura. O segundo, com atores de mercado, contou com 23 participantes das seguintes instituições: Associação Brasileira dos Dirigentes de Entidades Gestoras e Operadoras de Microcrédito (ABCRED), Associação Brasileira de Instituições Financeiras de Desenvolvimento (ABDE), Associação Brasileira de Sociedades de Crédito ao Microempreendedor e à Empresa de Pequeno Porte (ABSCM), Associação Nacional do Cooperativismo de Crédito da Economia Familiar e Solidária, Federação Brasileira de Bancos (Febraban), Organização das Cooperativas Brasileiras (OCB) e bancos cooperativos. E o terceiro, com fomentadores e estudiosos, contou com 13 participantes das seguintes instituições: Sebrae, Instituto de Estudos do Trabalho e Sociedade, Centro de Pesquisas em Microfinanças da Fundação Getulio Vargas em São Paulo (FGV/SP), FGV/RJ (em parceria com a Microfinance Information eXchange), International Finance Corporation, Banco Interamericano de Desenvolvimento, Planet Finance e Accion Internacional. 
No I Fórum, do qual participaram aproximadamente 300 convidados de fora, prosseguiram-se o diálogo e as parcerias iniciadas e realizou-se o diagnóstico a respeito das microfinanças no Brasil. Um dos resultados desse Fórum foi a identificação da necessidade de se organizar e consolidar dados e informações disponíveis no BC sobre o assunto, para efetivo diagnóstico do setor de microfinanças. Com esse propósito, o BC iniciou a publicação do Relatório de Inclusão Financeira (RIF), com duas edições até 2012. Na elaboração dos RIFs utilizaram-se, primordialmente, dados que as instituições supervisionadas pelo BC enviam, por exigência normativa, a essa autarquia, e dados do Instituto Brasileiro de Geografia e Estatística (IBGE). O RIF n. 1 (BC, 2010) consolidou e analisou dados sobre acesso e uso de serviços financeiros, além de apresentar informações sobre o cenário macroeconômico e sobre a estrutura e composição do Sistema Financeiro Nacional (SFN). O RIF n. 2 (BC, 2011), além de atualizar os dados apresentados no primeiro relatório, apresentou um índice de inclusão financeira (IIF) elaborado pelo BC, entre outras inovações. O IIF é um indicador sintético, composto a partir da agregação de indicadores de diferentes dimensões da inclusão financeira, como número de agências bancárias por adulto, quantidade de crédito disponível e volume de depósitos. É uma forma de traduzir o nível de inclusão em uma escala numérica, capaz de mostrar tendências gerais e comparar estados e municípios.

Um dos tópicos que, na visão da coordenação técnica do I Fórum, permeou todas as discussões dos grupos, foi sobre o papel de liderança exercido pelo BC na inclusão financeira. De forma geral, o BC foi apontado como a instituição mais apropriada para promover o diálogo entre reguladores, operadores e fomentadores - atores relevantes do processo de inclusão financeira. De fato, os citados eventos, reuniões e grupos de trabalho que a instituição organizou ou dos quais participou são exemplos de iniciativas do BC para a articulação e coordenação de atores.

Em 2010, o BC introduziu a "promoção da inclusão financeira" como um dos seus objetivos estratégicos, válido até 2014. Em consequência, nesse mesmo ano, instituiu um componente administrativo especialmente para tratar desse assunto e de questões relacionadas à responsabilidade socioambiental do sistema financeiro.

Em 2011, por iniciativa do BC e no âmbito do projeto Inclusão Financeira, foi lançada a Parceria Nacional para Inclusão Financeira (PNIF), uma "rede de atores públicos e privados engajados em ações coordenadas para a promoção da adequada inclusão financeira da população brasileira". Essa definição foi extraída do Plano de Ação para Fortalecimento do Ambiente Institucional, que é uma das iniciativas do PNIF. O referido Plano (de 2012, disponível em: http://www.bcb.gov.br/nor/relincfin/ Plano_de_Acao_PNIF.pdf) estabeleceu oito ações específicas a serem implementadas entre 2012 e 2014 , indicando as entidades diretamente envolvidas na coordenação de sua execução. O BC está presente em todas as coordenações. As demais entidades, que participam da coordenação de ao menos uma das ações, são: os ministérios da Fazenda, da Justiça, das Comunicações, do Desenvolvimento Social e Combate à Fome, o Ministério Público Federal, a Comissão de Valores Mobiliários (CVM), a Superintendência Nacional de Previdência Complementar (Previc), a Superintendência de Seguros Privados (Susep), o Sebrae, o IBGE e a Secretaria de Assuntos Estratégicos da Presidência da República. Essa multiplicidade de órgãos é necessária, entre outras razões, porque a inclusão financeira abarca temas de múltiplas competências, como, por exemplo, as diversas alçadas regulatórias dos serviços financeiros (exercidas pelo BC, CVM, Previc e Susep). Cabe destacar que as parcerias do BC para a inclusão financeira não se restringem à esfera pública. O BC mantém estreita relação com inúmeros atores privados, entre os quais se destacam as entidades de classe, tais como a Associação Brasileira de Bancos e as citadas OCB, Febraban, ABSCM, ABCRED e ABDE.

Merece destaque o "empreendedorismo da burocracia". Nas entrevistas, foi mencionado que a inclusão financeira teve uma série de apoiadores e empreendedores dentro do BC, mesmo antes do advento dos projetos estratégicos e da institucionalização via componente organizacional específico. Além das pessoas já citadas, 
vale destacar o Sr. Sérgio Darci, do Departamento de Normas do Sistema Financeiro, um dos principais responsáveis pela colocação do tema na agenda do BC; o Sr. Luiz Feltrim, então no Departamento de Organização do Sistema Financeiro, que apoiou fortemente iniciativas voltadas para a inclusão financeira (como os projetos estratégicos); e o Sr. Marden Soares, do mesmo departamento, que, por muito tempo, por iniciativa própria e cumulativamente ao seu trabalho corrente, levou a cabo atividades relacionadas à inclusão financeira. Essas pessoas foram evidenciadas pela relevância do seu papel na promoção da inclusão financeira dentro do BC. Ressalte-se que, conforme observado nas entrevistas, o rol de apoiadores e empreendedores é mais amplo. Inclui adeptos (por vezes entusiastas) do microcrédito e do cooperativismo de crédito, para mencionar dois dos assuntos mais "populares" - dentro e fora do BC - relacionados à inclusão financeira. Essas pessoas ficarão anônimas apenas porque não cabe ser exaustivo nas citações.

Foi observado que, nos RIFs, estão consolidados dados de acesso e uso de serviços financeiros no Brasil. Sobre o acesso da população a tais serviços, os principais dados e informações disponíveis nos RIFs encontram-se sumarizados no Quadro 1.

\section{Quadro 1 - Acesso a serviços financeiros: dados e informações disponíveis nos RIFs n. 1 (2010) e n. 2 (2011).}

\begin{tabular}{|c|c|c|}
\hline $\begin{array}{l}\text { O que está sendo } \\
\text { medido }\end{array}$ & RIF n. 1 (2010) & RIF n. 2 (2011) \\
\hline $\begin{array}{l}\text { Agências, postos } \\
\text { de atendimento, } \\
\text { correspondentes no } \\
\text { país e equipamentos } \\
\text { eletrônicos (a). }\end{array}$ & $\begin{array}{l}\text { - Quantidade por região e por } \\
\text { Unidade da Federação (UF); } \\
\text { - distribuição regional; } \\
\text { - quantidade por adultos, por } \\
\text { região e por UF; } \\
\text { - quantidade por km², por região } \\
\text { e por UF (b). }\end{array}$ & $\begin{array}{l}\text { - Distribuição regional de canais } \\
\text { de acesso, população adulta, } \\
\text { área territorial e PIB; } \\
\text { - quantidade por adultos, por } \\
\text { região; } \\
\text { - quantidade por } \mathrm{km}^{2} \text {, por } \\
\text { região; } \\
\text { - quantidade total, por } \mathrm{km}^{2} \text { e por } \\
\text { adultos. }\end{array}$ \\
\hline Agências bancárias & $\begin{array}{l}\text { - Comparação internacional } \\
\text { (Brasil x países em } \\
\text { desenvolvimento x países } \\
\text { desenvolvidos): quantidade } \\
\text { por adultos. }\end{array}$ & $\begin{array}{l}\text { - Comparação internacional } \\
\text { (Brasil x países em } \\
\text { desenvolvimento x países } \\
\text { desenvolvidos x América Latina } \\
\text { e Caribe): quantidade por } \\
\text { adultos. }\end{array}$ \\
\hline $\begin{array}{l}\text { Correspondentes no } \\
\text { país }\end{array}$ & - Quantidade por região. & $\begin{array}{l}\text { - Distribuição regional por tipo } \\
\text { de instituição contratante; } \\
\text { - distribuição regional por tipo } \\
\text { de atividade autorizada; } \\
\text { - quantidade total, por } \\
\text { instituição contratante; } \\
\text { - quantidade total, por tipo de } \\
\text { atividade autorizada. }\end{array}$ \\
\hline $\begin{array}{l}\text { Equipamentos } \\
\text { eletrônicos }\end{array}$ & $\begin{array}{l}\text { - ATM e POS - comparação } \\
\text { internacional (Brasil x países } \\
\text { em desenvolvimento x países } \\
\text { desenvolvidos): quantidade/ } \\
\text { adultos. }\end{array}$ & $\begin{array}{l}\text { ATM - comparação } \\
\text { internacional (Brasil x países } \\
\text { em desenvolvimento x países } \\
\text { desenvolvidos x América Latina e } \\
\text { Caribe): quantidade por adultos. }\end{array}$ \\
\hline Acesso remoto (c) & $\begin{array}{l}\text { Quantidade de usuários nos } \\
\text { canais. }\end{array}$ & - \\
\hline
\end{tabular}

Continua 
Continuação

Nível de acesso dos municípios (capilaridade)
- Quantidade e porcentagem de municípios atendidos apenas por correspondente e por correspondente e/ou PAE;

- quantidade de municípios por nível de acesso;

- distribuição regional dos municípios atendidos apenas por correspondente;

- distribuição regional dos municípios atendidos por três ou quatro tipos de canal de acesso;

- porcentagem de municípios por nível de acesso, por região e por UF.
- Distribuição dos municípios em função da quantidade de agências bancárias, por faixa de população adulta e por faixa de área territorial;

- distribuição dos municípios em função da quantidade de pontos de atendimento bancário, por faixa de população adulta;

- distribuição dos municípios em função da presença de agências, correspondentes e PAAs, por faixa de população adulta; - distribuição dos municípios com mais de $10.000 \mathrm{~km}^{2} \mathrm{e}$ com cinco ou menos pontos de atendimento, por faixa de população adulta.

Fonte: BC (2010; 2011).

\section{Notas:}

(a) Postos de atendimento: Posto de Atendimento Bancário (PAB), Posto Avançado de Atendimento (PAA), Posto de Atendimento Bancário Eletrônico (PAE), Posto de Atendimento Cooperativo (PAC) e Posto de Atendimento de Microcrédito (PAM). Equipamentos eletrônicos: caixas de autoatendimento (ATM) e máquinas de leitura de cartões de pagamento (POS). Para a explicação desses canais de acesso a serviços financeiros, vide: BC, 2011, p. 27-29.

(b) Não inclui os Postos de Atendimento de Microcrédito (PAM).

(c) Por acesso remoto "entendem-se os canais de acesso a serviços bancários que podem ser acessados por intermédio de equipamentos que pertencem ao próprio usuário, tais como telefone fixo ou móvel, computadores pessoais etc., a saber: call centers, internet e mobile banking" (BC, 2010, p. 64).

Quanto aos principais dados e informações disponíveis nos RIFs sobre o uso de serviços financeiros pela população, encontram-se sumarizados no Quadro 2.

\section{Quadro 2 - Uso de serviços financeiros: dados e informações disponíveis nos RIFs n. 1 (2010) e n. 2 (2011).}

\begin{tabular}{|c|c|c|}
\hline $\begin{array}{c}\text { O que está sendo } \\
\text { medido }\end{array}$ & RIF n. 1 (2010) & RIF n. 2 (2011) \\
\hline Crédito em geral & $\begin{array}{l}\text { - Volume de crédito sobre PIB; } \\
\text { - distribuição do volume de } \\
\text { crédito para pessoas físicas } \\
\text { (PFs) por faixa de valor da } \\
\text { operação; } \\
\text { - volume de crédito por } \\
\text { adultos; volume de crédito de } \\
\text { PFs e pessoas jurídicas (PJs), } \\
\text { por região; } \\
\text { - quantidade de operações, por } \\
\text { faixa de valor e região; } \\
\text { - quantidade de operações na } \\
\text { carteira de crédito ativa, por } \\
\text { adultos; } \\
\text { - inadimplência de PFs e PJs, } \\
\text { por região. }\end{array}$ & $\begin{array}{l}\text { - Volume de crédito sobre PIB; } \\
\text { - volume de crédito por } \\
\text { modalidade; } \\
\text { - participação do crédito } \\
\text { habitacional no total PF; } \\
\text { - distribuição do volume de crédito } \\
\text { para PFs por faixa de valor da } \\
\text { operação; } \\
\text { - volume de crédito por adultos; } \\
\text { - quantidade de operações, por } \\
\text { faixa de valor e região; } \\
\text { - quantidade de operações, por } \\
\text { saldo devedor e região; } \\
\text { - quantidade de operações, por } \\
\text { adultos; } \\
\text { - inadimplência de PFs e PJs, por } \\
\text { região; }\end{array}$ \\
\hline
\end{tabular}

Continua 
Continuação

\begin{tabular}{|c|c|c|}
\hline Crédito em geral & & $\begin{array}{l}\text { - crédito médio por contrato sobre } \\
\text { PIB per capita, por UF; } \\
\text { - número de contratos de crédito } \\
\text { de PF por população adulta, por } \\
\text { UF; } \\
\text { - número de contratos de crédito } \\
\text { de PF por população adulta, por } \\
\text { região; } \\
\text { - crédito médio por contrato sobre } \\
\text { PIB per capita, por região; } \\
\text { - volume de crédito para PFs por } \\
\text { adultos, por UF e por região; } \\
\text { - composição da carteira de crédito } \\
\text { de PFs (abaixo ou acima de } \\
\text { R\$ } 5 \text { mil), por UF e por região; } \\
\text { - volume de crédito para PJs por } \\
\text { porte da empresa, por UF e } \\
\text { região; } \\
\text { - volume de crédito médio para } \\
\text { microempresas, por UF; } \\
\text { - volume de crédito médio para } \\
\text { pequenas empresas, por UF; } \\
\text { - taxa de juros média para PJs, } \\
\text { por porte da empresa; } \\
\text { - taxa de juros média para PJs, } \\
\text { por porte de crédito. }\end{array}$ \\
\hline Microcrédito & $\begin{array}{l}\text { - Volume de recursos } \\
\text { de depósitos à vista } \\
\text { destinados a operações } \\
\text { de microcrédito, exigido e } \\
\text { aplicado, segmentado por } \\
\text { direcionamento; } \\
\text { - quantidade de contratos } \\
\text { e volume de recursos de } \\
\text { operações no âmbito do } \\
\text { Programa Nacional de } \\
\text { Microcrédito Produtivo } \\
\text { orientado. }\end{array}$ & $\begin{array}{l}\text { - Volume de recursos de depósitos } \\
\text { à vista aplicados a operações de } \\
\text { microcrédito, segmentado por } \\
\text { direcionamento; } \\
\text { - porcentagem aplicada pelos } \\
\text { bancos públicos federais e pelas } \\
\text { demais instituições, segmentado } \\
\text { por direcionamento; } \\
\text { - direcionamento de depósitos } \\
\text { à vista para operações de } \\
\text { microfinanças. }\end{array}$ \\
\hline Crédito rural & $\begin{array}{l}\text { - Quantidade de contratos e } \\
\text { volume de recursos por ano } \\
\text { agrícola, total e no âmbito } \\
\text { do Programa Nacional de } \\
\text { Favorecimento da Agricultura } \\
\text { Familiar (Pronaf); } \\
\text { - distribuição do crédito do } \\
\text { Pronaf, por região e por UF. }\end{array}$ & $\begin{array}{l}\text { - Volume de recursos do crédito } \\
\text { rural total e Pronaf; } \\
\text { - valor médio por contrato; } \\
\text { - quantidade de contratos e } \\
\text { volume de recursos por ano } \\
\text { agrícola, total e no âmbito do } \\
\text { Pronaf; } \\
\text { - número de contratos e valores } \\
\text { por limite de financiamento; } \\
\text { - número, volume e valor médio } \\
\text { dos contratos do Pronaf, por } \\
\text { região. }\end{array}$ \\
\hline Crédito imobiliário & - & $\begin{array}{l}\text { - Contratações do Programa Minha } \\
\text { Casa Minha Vida, por região. }\end{array}$ \\
\hline
\end{tabular}

Continua 


\begin{tabular}{|c|c|c|}
\hline Depósitos & $\begin{array}{l}\text { - Volume de depósitos totais, a } \\
\text { prazo, de poupança e à vista; } \\
\text { - volume de depósitos totais, } \\
\text { por região; } \\
\text { - volume de depósitos totais } \\
\text { sobre PIB regional e nacional; } \\
\text { - volume de depósitos totais } \\
\text { por adultos, nacional e por } \\
\text { região; } \\
\text { - depósito à vista médio sobre } \\
\text { renda per capita; } \\
\text { - número de contas de depósito } \\
\text { à vista por adultos; } \\
\text { - depósito de poupança médio } \\
\text { sobre renda per capita; } \\
\text { - número de depósitos à vista } \\
\text { por adultos; } \\
\text { - depósito de poupança médio } \\
\text { por cliente sobre renda per } \\
\text { capita; } \\
\text { - média semestral de contas } \\
\text { de depósitos à vista sobre } \\
\text { população adulta; } \\
\text { - número de contas-correntes } \\
\text { e contas poupança } \\
\text { simplificadas, total e ativas. }\end{array}$ & $\begin{array}{l}\text { - Quantidade de PFs com } \\
\text { relacionamentos ativos; } \\
\text { - quantidade de clientes com } \\
\text { contas poupança, por faixa de } \\
\text { valor; } \\
\text { - quantidade de clientes com } \\
\text { contas poupança, por adultos; } \\
\text { - quantidade de pontos de } \\
\text { captação de poupança; } \\
\text { - quantidade de contas de } \\
\text { depósitos à vista; } \\
\text { - volume de depósitos totais, a } \\
\text { prazo, de poupança e à vista; } \\
\text { - volume de depósitos totais, a } \\
\text { prazo, de poupança e à vista, por } \\
\text { adultos; } \\
\text { - volume de depósitos totais, por } \\
\text { região e UF; } \\
\text { - volume de depósitos totais por } \\
\text { adultos, por região e UF; } \\
\text { - número de contas-correntes e } \\
\text { contas poupança simplificadas, } \\
\text { total e ativas. }\end{array}$ \\
\hline $\begin{array}{l}\text { Instrumentos de } \\
\text { pagamento e canais } \\
\text { de distribuição (a) }\end{array}$ & $\begin{array}{l}\text { - Número de transações com } \\
\text { cheque, cartão de crédito, } \\
\text { de débito e transferência de } \\
\text { crédito; } \\
\text { - número de cartões de crédito } \\
\text { e de débito, emitidos e } \\
\text { ativos; } \\
\text { - número de cartões de crédito } \\
\text { e de débito, emitidos e ativos, } \\
\text { por adultos; } \\
\text { - valor médio por operação de } \\
\text { cartão de crédito e de débito; } \\
\text { - número de transações por } \\
\text { canal de distribuição; } \\
\text { - número de transações (uso } \\
\text { em pagamentos) por canal de } \\
\text { distribuição; } \\
\text { - número de transações (uso } \\
\text { em pagamento de conta, } \\
\text { de tributo e transferência } \\
\text { de crédito), por canal de } \\
\text { distribuição; } \\
\text { - volume de recursos } \\
\text { movimentados e número } \\
\text { de transações por internet } \\
\text { banking, por tipo de } \\
\text { transação; }\end{array}$ & $\begin{array}{l}\text { - Número de transações com } \\
\text { cheque, cartão de crédito, de } \\
\text { débito e transferência de crédito; } \\
\text { - número de cartões de crédito e } \\
\text { de débito, emitidos e ativos; } \\
\text { - número de cartões de crédito e } \\
\text { de débito, emitidos e ativos, por } \\
\text { classe de renda; } \\
\text { - número de cartões de crédito e } \\
\text { de débito, emitidos e ativos, por } \\
\text { adultos; } \\
\text { - valor médio por operação de } \\
\text { cartão de crédito e de débito; } \\
\text { - número de transações por canal } \\
\text { de distribuição; } \\
\text { - número de transações em } \\
\text { operações financeiras por canal } \\
\text { de distribuição; } \\
\text { - número de transações em } \\
\text { operações não financeiras por } \\
\text { canal de distribuição; } \\
\text { - número de transações (uso } \\
\text { em pagamentos) por canal de } \\
\text { distribuição; } \\
\text { - número de transações (uso em } \\
\text { pagamento de conta, de tributo } \\
\text { e transferência de crédito), por } \\
\text { canal de distribuição; }\end{array}$ \\
\hline
\end{tabular}


Continuação

\begin{tabular}{|c|c|c|}
\hline $\begin{array}{l}\text { Instrumentos de } \\
\text { pagamento e canais } \\
\text { de distribuição (a) }\end{array}$ & $\begin{array}{l}\text { - volume de recursos } \\
\text { movimentados e número de } \\
\text { transações por ATMs, por tipo } \\
\text { de transação. }\end{array}$ & $\begin{array}{l}\text { - volume de recursos } \\
\text { movimentados e número de } \\
\text { transações por internet banking, } \\
\text { por tipo de transação; } \\
\text { - volume de recursos } \\
\text { movimentados e número de } \\
\text { transações por ATMs, por tipo de } \\
\text { transação. }\end{array}$ \\
\hline $\begin{array}{l}\text { Acesso a serviços } \\
\text { financeiros por } \\
\text { unidades familiares }\end{array}$ & - & $\begin{array}{l}\text { - Porcentagem de famílias que } \\
\text { possuem conta-corrente, } \\
\text { poupança, cartão de débito, } \\
\text { cartão de crédito e cheque, por } \\
\text { classe econômica; } \\
\text { - formas de pagamento mais } \\
\text { frequentes, participação } \\
\text { percentual por classe econômica; } \\
\text { - formas de recebimento de salário } \\
\text { da população economicamente } \\
\text { ativa, participação percentual por } \\
\text { classe econômica. }\end{array}$ \\
\hline $\begin{array}{l}\text { Projeto de Inclusão } \\
\text { Bancária para } \\
\text { beneficiários do } \\
\text { Programa Bolsa } \\
\text { Família (PBF) }\end{array}$ & - & $\begin{array}{l}\text { - Famílias do Projeto de Inclusão } \\
\text { Bancária em relação ao total de } \\
\text { famílias PBF; } \\
\text { - uso de produtos financeiros pelas } \\
\text { famílias do PBF participantes do } \\
\text { Projeto de Inclusão Bancária; } \\
\text { - quantidade de famílias pagas por } \\
\text { canal. }\end{array}$ \\
\hline
\end{tabular}

Fonte: BC (2010; 2011).

\section{Nota:}

(a) Conforme definição do Bank for International Settlements (BIS), instrumento de pagamento é "qualquer instrumento que permita ao portador/usuário transferir fundos" (BC, 2011, p. 93). Exemplos desses instrumentos são o dinheiro, cheque, débito direto e transferências de crédito (como bloqueto de cobrança), cartões de pagamento e mobile payment. Canais de distribuição (ou de acesso): agências, postos de atendimento, correspondentes, equipamentos eletrônicos (ATM, POS e dispositivos móveis com acesso a internet banking), centrais de atendimento (call center) e internet banking (home e office banking).

O plano do projeto previa a realização de pesquisas qualitativas, necessárias, entre outros motivos, para avaliar a adequação dos serviços financeiros às necessidades da população. Entretanto, conforme relatado nas entrevistas, passado um tempo, com a experiência das parcerias formadas e tendo conhecido melhor o mercado de pesquisa sobre inclusão financeira (e sendo conhecido por ele), a equipe do projeto chegou à conclusão de que a demanda por pesquisas qualitativas poderia ser suprida por outras instituições, públicas e privadas, com interesse e capacitação para levar a cabo tal atividade. No período analisado (2009 a 2012), destacam-se as pesquisas relacionadas à inclusão financeira feitas pela Confederação Nacional da Indústria (CNI), Fundação Melinda e Bill Gates e Instituto de Pesquisa Econômica Aplicada (IPEA). As duas primeiras tiveram o apoio do BC na forma de comentários técnicos às versões de seus instrumentos de pesquisa, enquanto a do IPEA, de acordo com informações obtidas nas entrevistas, pode vir a ser revista com a ajuda da equipe do projeto. 
Tendo em vista a definição de inclusão financeira adotada pelo $B C$, anteriormente transcrita (cf. BC, 2010, p. 18; BC, 2011, p. 15), e em resposta à questão secundária de pesquisa, precisariam ser avaliados, no mínimo, os seguintes aspectos da política pública de inclusão financeira liderada pelo BC:

o acesso da população brasileira a serviços financeiros;

o uso desses serviços pela população;

a adequação desses serviços às necessidades da população.

Sobre a adequação, não há dados e informações nos RIFs relativos a esse aspecto. Trata-se de uma informação essencialmente qualitativa, que pode estar presente nas mencionadas pesquisas da CNI, da Fundação Melinda e Bill Gates e do IPEA, que não foram analisadas. Quanto aos aspectos de acesso e uso de serviços financeiros, em larga medida, os dados e informações reunidos e organizados nos RIFs (sumarizados nos Quadros 1 e 2 da seção anterior) podem ser considerados suficientes para avaliá-los. Há, contudo, uma lacuna importante: o uso de serviços financeiros por canal de acesso. Essa informação cruzada (uso versus canal), exceto de maneira sintética, por meio do índice de inclusão financeira, não aparece nos RIFs. Sem tal informação não se sabe, por exemplo, qual é o volume de crédito concedido via correspondente bancário, ou quanto os correspondentes têm captado de poupança. São informações importantes para se avaliar, de forma mais completa, a efetividade de se fomentar esse canal como forma de promover a inclusão financeira (o raciocínio vale para os demais canais). Como foi visto, a inclusão financeira não se limita ao acesso a meios de pagamento e recebimento, mas deve incluir o acesso "à gama completa de produtos financeiros" (WEISSBOURD, 2002, p. 3), de forma a ajudar as pessoas a escaparem de uma existência da-mão-para-a-boca (MAS, 2009).

A explicação para a não existência nos RIFs da informação de uso por canal de acesso está em que essa informação não consta entre aquelas que as instituições supervisionadas pelo BC devem enviar a essa autarquia. E, conforme declarou a gerente do projeto, havia uma quantidade enorme de dados e informações dentro do BC quando se iniciou a preparação dos RIFs (esparsos, não compilados), de forma que a equipe do projeto optou por explorar essa base primeiro, não pedindo dados e informações extras às instituições financeiras. Nesse primeiro momento, compreende-se a dificuldade do BC em ir além das próprias bases de dados. Mas o esforço extra, necessário para obter a citada informação (uso de serviços financeiros por canal), em algum momento terá que ser empreendido, caso se queira fazer uma avaliação cabal da política de inclusão financeira liderada pelo BC. No caso, uma tal empreitada esbarra em uma série de dificuldades: questões de custos para o SFN, que adviriam do fornecimento ao BC de dados e informações extras; a provável resistência de instituições financeiras que adotam os correspondentes em mostrar dados e informações sensíveis, por reveladores de estratégias comerciais; o trabalho extra para os departamentos do BC que administram as bases de dados que seriam afetadas e, eventualmente, para o departamento que cuida da infraestrutura de informações. Para superar essas dificuldades, não bastará competência técnica. Conforme ponderou a gerente do projeto, será preciso contar com um forte apoio interno, convencer pessoas, lidar com interesses conflitantes, negociar. Em suma, será preciso aliar à capacidade técnica a capacidade de articulação política (FARAH, 2011; O'TOOLE JUNIOR, 2010; WEISS, 1999; REIS, 1989).

Neste ponto, cabe recuperar a questão principal de pesquisa, expressa na introdução do artigo: qual é a relação entre (i) as atividades de articulação política desenvolvidas para a obtenção dos dados e informações necessários para avaliar a política pública e (ii) a disponibilidade (ou indisponibilidade) desses dados e informações?

A mencionada capacidade de articulação foi posta em prática pela equipe do projeto para obter dados armazenados em bases de dados administradas por outros departamentos. A gerente, conforme relatado em entrevista, tomou a iniciativa de procurar o chefe do departamento que, na época, administrava a base de dados de 
informações de crédito para explicar-Ihe o projeto. Seu propósito foi, fundamentalmente, facilitar a necessária integração entre sua equipe e os responsáveis pela referida base de dados: aplainar o caminho. Conforme O'Toole Junior (2010), não se pode assumir que existe apoio, mas sim trabalhar para obtê-lo. Mais que uma questão técnica, tratou-se de uma iniciativa política - política organizacional, no caso. Porque também nas organizações há embate de interesses e pressões conflitantes, seja em torno de orçamento, prioridades, espaço ou qualquer outro assunto capaz de gerar disputas entre pessoas ou áreas. Recorde-se, a esse respeito, a afirmativa de Weiss (1999, p. 471) sobre a "endêmica prioridade da 'política' em todas as organizações". Do mesmo modo que essa autora, constatamos a presença da variável política não como quem "flagra" um malfeito ou um mal necessário, na medida em que o fator político em si mesmo é positivo, ainda que possa degradar-se, como quase tudo.

Se a política tem a ver com embate de interesses conflitantes (WEISS, 1999), também fazem parte dela contatos, articulações e coalizões (O'TOOLE JUNIOR, 2010; SOUZA, 2006; KINGDON, 1995b; SABATIER, 1991). Um exemplo são as redes sociais, formadas pelos empreendedores de políticas, que emergem do modelo de arenas sociais. Esses empreendedores envidam esforços para promover uma determinada política que Ihes favoreça ou na qual acreditam, formando redes com outros empreendedores, por meio de contatos, vínculos e conexões (SOUZA, 2006). Analogicamente, pode-se aplicar esse modelo não para o lançamento de uma política, mas para a viabilização da avaliação de uma política. Foi o caso dos RIFs, elaborados no âmbito do projeto, com o comprometimento da equipe do projeto e de pessoas não vinculadas formalmente a ele, mas envolvidas com a questão da inclusão financeira. Como foi dito, microcrédito e cooperativismo de crédito são dois assuntos com adeptos entusiastas, e muitos dos apoiadores e empreendedores anônimos aos quais se aludiu na descrição do caso constituíram uma verdadeira rede social, razoavelmente bem articulada para dentro e para fora do BC.

Conforme mencionado nas entrevistas, para obter certos dados do IBGE, necessários para a montagem de alguns indicadores demográficos e geográficos apresentados nos RIFs n. 1 e n. 2, também foi preciso articular-se. O principal canal de contato da gerente do projeto com aquela instituição foram pessoas do Departamento Econômico do BC (Depec) no Rio de Janeiro. Quer dizer, foi um contato mediado por essas pessoas que, por razões profissionais, tinham uma conexão direta com pessoas do IBGE. As competências da gerente do projeto que suportaram a articulação foram basicamente de mapeamento de informações e gestão de contatos internos. Adicionalmente, a gerente também fez um contato direto com a Diretora de Pesquisa do IBGE, mas posteriormente à época da elaboração dos citados RIFs.

O contato com o IBGE é um exemplo de aproximação com atores externos ao BC motivada pela necessidade de viabilizar a avaliação da política em estudo. Mas muitos outros contatos também serviram a esse propósito, sem que fosse esse o objetivo principal da aproximação. É o caso dos Fóruns Banco Central sobre Inclusão Financeira e as reuniões e encontros que os precederam. Outro exemplo são as coordenações do Plano de Ação para Fortalecimento do Ambiente Institucional, das quais fazem parte 0 $\mathrm{BC}$ e os demais reguladores de serviços financeiros (CVM, Previc e Susep). Em consonância com a observação de Rabell (apud FARAH, 2011) de que as políticas públicas têm dependido cada vez mais da coordenação de diversas jurisdições, a inclusão financeira caracteriza-se por abarcar múltiplas alçadas. O citado autor fala também de como as políticas públicas têm dependido da articulação com atores governamentais e não governamentais. Vão nessa direção os mencionados fóruns, com suas reuniões e encontros preparatórios. Ressalte-se que a articulação com atores externos foi um objetivo explícito do BC ao organizar esses eventos.

Os exemplos anteriormente citados relacionam-se a iniciativas da equipe do projeto Inclusão Financeira. Ilustram aspectos de articulação política e coordenação de atores postas em prática, entre outros objetivos, para obter os dados e informações necessários à avaliação, formal ou informal, da política em foco no período considerado (2009-2012). A propósito, cabe observar que iniciativas dessa natureza não foram "inauguradas" com o referido projeto. Na descrição do caso, foi mencionado o grupo 
de trabalho constituído por técnicos do BC, representantes do setor cooperativista de crédito e parlamentares para a edição da Resolução n. 2.608, de 1999, assim como o grande envolvimento do BC com o citado setor na evolução normativa que se seguiu àquela Resolução (recorde-se: envolvimento que não foi apenas técnico, mas político também). Na seção anterior, também foram mencionados os seminários organizados pelo BC entre 2002 e 2008, que fomentaram o contato da instituição com a indústria microfinanceira. O I Fórum Banco Central de Inclusão Financeira (em 2009, já no âmbito do projeto), que incluía entre seus objetivos a articulação com atores externos, certamente não partiu do zero em termos de formação de parcerias externas.

A capacidade de articulação política ajudou a obter apoios dentro e fora do BC. Não obstante, foi importante institucionalizar, via projeto estratégico, a participação dos departamentos cuja contribuição era imprescindível. Os chefes de todos os departamentos que fazem parte do projeto assinam o documento pelo qual ele é formalizado. Esse documento inclui os objetivos e os produtos esperados, assim como prazos e recursos. Se não garante a mais franca colaboração dos departamentos envolvidos, ajuda a promover a coordenação de esforços dos participantes. O projeto, no BC, é uma combinação das estruturas para a coordenação que Brinkerhoff (1996) chamou de "mercado" e "hierarquia". Pessoas e grupos tiveram um alto grau de liberdade, ao mesmo tempo em que houve, via projeto, certa coordenação central e hierárquica. Constatou-se a existência de um patrocínio forte e efetivo ao projeto, o que contribuiu para que essa estrutura funcionasse a contento. Identificaram-se como patrocinadores - que atuaram como verdadeiros "empreendedores de política" (KINGDON, 1995a) - o Sr. Alexandre Tombini, então Diretor de Normas e Organização do Sistema Financeiro, e o Sr. Luiz Feltrim, então Chefe do Departamento de Organização do Sistema Financeiro (Deorf). Esse último teve uma presença mais próxima, como chefe da unidade dentro da qual nasceu o projeto (o Deorf era a "unidade interessada", no jargão de gestão de projetos do BC). Merece destaque a atuação desses empreendedores, assim como dos demais apoiadores da inclusão financeira dentro do BC. Eles ajudaram a colocar - e depois a manter - o assunto na agenda da instituição e a apoiá-lo com recursos (por exemplo, garantindo um orçamento fixo, via projeto, ou apoiando demandas financeiras ocasionais). Para a maioria dos apoiadores, o suporte concretizou-se não como uma ocupação habitual, de rotina, mas como "disposição" ou "abertura". Acessar essa abertura - conectar-se, articular-se - foi um dos trabalhos importantes da equipe do projeto, que precisou fazer o mesmo com os apoiadores externos. Trabalho importante e nem sempre fácil. Obter e manter os apoios exigiu um esforço continuado da equipe do projeto, já que a boa disposição dos apoiadores, por uma variedade de razões (outros compromissos, outras prioridades), não significou acesso imediato ou fácil.

\section{Comelursões}

Respondendo à questão da pesquisa principal, concluímos que as atividades de articulação política contribuíram destacadamente na obtenção dos dados e informações necessários à avaliação da política pública de inclusão financeira liderada pelo BC. Tomem-se, como exemplo, os esforços de articulação interna da equipe do projeto Inclusão Financeira com os responsáveis pelas bases de dados do BC, e de articulação externa com instituições que realizam pesquisas qualitativas sobre o assunto. No que se refere à indisponibilidade de dados e informações, identificamos o uso de serviços financeiros por canal de acesso como uma lacuna importante nos Relatórios de Inclusão Financeira do BC, mas não foi possível estabelecer uma relação de causalidade entre essa lacuna e possíveis falhas de articulação política.

O referencial teórico, que destaca a variável política em contextos específicos injunções e motivações políticas no uso das avaliações, o processo de decisão como construção política, a polaridade administração e política -, mostrou-se adequado para o contexto do caso em estudo: o processo de obtenção de dados e informações para avaliar uma política pública. 
As atividades técnicas relacionadas à avaliação da política pública em tela não foram abordadas (ou foram tocadas apenas superficialmente) porque o foco deste artigo eram as atividades de articulação política. Com essa observação - que recupera uma ideia presente tanto na introdução do artigo quanto no referencial teórico -, queremos ressaltar a importância que atribuímos a ambos os aspectos, capacidade técnica e capacidade de articulação política, para viabilizar a avaliação de uma política pública. As atividades preparatórias do I Fórum Banco Central sobre Inclusão Financeira são um bom exemplo de união dessas capacidades, o que contribuiu para o diagnóstico do setor microfinanceiro no Brasil. Se ambas as capacidades são importantes, recordamos, por oportuno, as ponderações de Reis (1989) e Aberbach, Rockman e Putnam (1981) sobre a não conveniência da fusão completa entre burocratas (técnicos) e políticos, que geraria o tipo "híbrido puro". Não é essa espécie de "tecnopolítico" que se defende, mas o técnico competente que seja também, na medida do possível, articulado e articulador.

Farah (2011) cita autores que entendem ter havido reintrodução da separação entre política e administração no interior mesmo da análise de políticas públicas. Com base nessas críticas, ainda segundo Farah (2011), autores pós-positivistas voltam a repudiar as abordagens tecnocráticas e economicistas da administração pública. Não fazia parte do escopo da pesquisa "medir" a facilidade ou a dificuldade de o corpo técnico do $B C$ articular-se politicamente. Uma hipótese possível é que, em uma organização de tradição tecnocrática como o BC, a habilidade de articulação política não seja suficientemente valorizada - no âmbito, por exemplo, da avaliação de desempenho, da avaliação de projetos ou, mais difusamente, na esfera da cultura organizacional. Isso seria um obstáculo para o exercício daquela habilidade. É apenas uma hipótese; testá-la, uma proposição de pesquisa. Uma variante dessa proposta de pesquisa seria estudar formas de desenvolver a capacidade de articulação política em organizações de corte tecnocrático. Por exemplo, por meio da inclusão de tópicos como "mapeamento e articulação de atores" e "desenvolvimento de contatos internos e externos" no rol de competências esperadas dos gerentes (o que repercute na avaliação de desempenho e no treinamento e desenvolvimento), assim como nos protocolos de planejamento e de avaliação de projetos. Ou estudar a efetividade de tópicos desse gênero - por que funcionam ou por que não funcionam -, se já estiverem presentes formalmente nos processos da organização. Em qualquer caso, a premissa, reforçada pela presente pesquisa, é que a capacidade de articulação política é algo positivo, por vezes necessário.

Por fim, cabe sublinhar que a política de inclusão financeira, no âmbito do governo federal em geral, como também do BC, é anterior ao corte temporal adotado (2009-2012) e não se limita às ações emanadas dessa instituição. O fato de o caso estudado restringir-se à esfera do $\mathrm{BC}$ e de ser essa autarquia a fonte única dos dados primários são limitações da pesquisa aqui retratada.

Referências

ABERBACH, J.; ROCKMAN, B.; PUTNAM, R. Bureaucrats and politicians in Western democracies. Cambridge: Harvard University Press, 1981.

ANDRADE, M. M. T. Gestão do acesso ao conhecimento externo em administradoras de carteira de investimentos imobiliários: estudo de casos. 2008. Tese (Doutorado)-Faculdade de Economia, Administração e Contabilidade da Universidade de São Paulo, São Paulo, 2008.

ARRETCHE, M. Tendências no estudo sobre avaliação. In: RICO, E. Avaliação de políticas: uma questão em debate. São Paulo: Cortez; IEE/PUC/SP, 1998. p. 29-39.

BC. BANCO CENTRAL DO BRASIL. Relatório de Inclusão Financeira, n. 1. Brasília, DF: 2010. 
BC. BANCO CENTRAL DO BRASIL. Relatório de Inclusão Financeira, n. 2. Brasília, DF: 2011.

BRINKERHOFF, D. W. Process perspectives on policy change: highlighting implementation. World Development, v. 24, n. 9, p. 1395-1401, 1996.

COHEN, E.; FRANCO, R. Evaluación de projectos sociales. México: Siglo XXI, 1992.

DEMIRGUC-KUNT, A.; KLAPPER, L. Measuring financial inclusion - the Global Findex Database. The world bank, development research group, finance and private sector development team. Policy Research Working Paper 6025, abr. 2012.

DIAS, D.; SELTZER, Y. Incluindo milhões hoje e amanhã: políticas e ações viáveis para um sistema financeiro inclusivo no Brasil. In: FELTRIM, L. E.; VENTURA, E. C. F.; DODL, A. B. (Coord.). Perspectivas e desafios para inclusão financeira no Brasil: visão de diferentes atores. Brasília: Banco Central do Brasil, 2009. p. 241-254.

DINIZ, E.; BIROCHI, R.; POZZEBON, M. Triggers and barriers to financial inclusion: the use of ICT-based branchless banking in an Amazon county. Eletronic Commerce Research and Applications, v. 11, p. 484-494, 2012.

DINIZ, E.; GONZALEZ, L. Sobre a inclusão financeira. Jornal Valor Econômico, São Paulo, 6 jun. 2013. Seção Opinião.

DYE, T. R. Understanding public policy. Englewood Cliffs: Prentice Hall, 1992.

FARAH, M. F. S. Administração pública e política pública. Revista de Administração Pública, v. 45, n. 3, p. 813-836, 2011.

FARIA, C. A. P. A política da avaliação de políticas públicas. Revista Brasileira de Ciências Sociais, São Paulo, v. 20, n. 59, p. 97-109, out. 2005.

FREY, K. Políticas públicas: um debate conceitual e reflexões referentes à prática da análise de políticas públicas no Brasil. Planejamento e Políticas Públicas, Brasília, DF, n. 21, p. 211-259, jun. 2000.

FELTRIM, L. E.; VENTURA, E. C. F.; DODL, A. B. Inclusão financeira no Brasil: projeto estratégico do Banco Central. In: FELTRIM, L. E.; VENTURA, E. C. F.; DODL, A. B. (Coord.). Perspectivas e desafios para inclusão financeira no Brasil: visão de diferentes atores. Brasília, DF: Banco Central do Brasil, 2009. p. 13-26.

FREITAS, M. L.; DAMIAN, D.; GIUSTI, S. Cooperativas de crédito: inclusão financeira com impactos sociais positivos. In: FELTRIM, L. E.; VENTURA, E. C. F.; DODL, A. B. (Coord.). Perspectivas e desafios para inclusão financeira no Brasil: visão de diferentes atores. Brasília, DF: Banco Central do Brasil, 2009. p. 113-129.

HAMMERSLEY, M.; GOMM, R.; FOSTER, P. Case study and theory. In: GOMM, R.; HAMMERSLEY, M.; FOSTER, P. Case study method. London: Sage, 2009.

HOWLETT, M.; RAMESH, M.; PERL, A. Política pública: seus ciclos e subsistemas (uma abordagem integradora). Rio de Janeiro: Elsevier, 2013.

JANNUZZI, P. M. Avaliação de programas sociais no Brasil: repensando práticas e metodologias das pesquisas avaliativas. Planejamento e Políticas Públicas, Brasília, DF, n. 36, 2011.

KINGDON, J. W. Agendas, alternatives, and public policies. Nova York: Harper Collins College Publishers, 1995a.

KINGDON, J. W. Agenda setting. In: THEODOULOU, S. Z.; CAHN, M. A. Public policy: the essential readings. Upper Saddle River: Prentice Hall, 1995b.

LINDBLOM, C. O processo de decisão política. Brasília, DF: Ed. Universidade de Brasília, 1981.

MAS, I. The economics of branchless banking. Innovations, v. 4, n. 2, p. 57-75, Spring, 2009. 
NUNES, E. Gramática política do Brasil: clientelismo e insulamento burocrático. Rio de Janeiro: Jorge Zahar, 2003.

O'TOOLE JUNIOR, L. Relações inteorganizacionais no processo de implementação. In: PETERS, G.; PIERRE, J. (Org.). Administração pública: coletânea. São Paulo: Unesp; Brasília, DF: Enap, 2010. p. 229-248.

PACHECO, S. R. Critérios de nomeação para cargos de direção no setor público. Desigualdade \& Diversidade. Dossiê Especial, p. 21-30, $2^{\circ}$ semestre, 2011.

PINTO, A. M. R. Fetichismo da avaliação. Análise e Conjuntura. Belo Horizonte: Fundação João Pinheiro, v. 1, n. 2, mai./ago. 1986.

REIS, E. R. Política e políticas públicas na transição democrática. Revista Brasileira de Ciências Sociais, v. 3, n. 9, fev. 1989. Disponível em: <http://www.anpocs.org. br/portal/publicacoes/rbcs_00_09/rbcs09_02.htm>. Acesso em: 1 nov. 2012.

ROSSI, P. H. et al. Evaluation: a systematic approach. Thousand Oaks: Sage, 2004.

SABATIER, P. A. Political science and public policy. In: SABATIER, P. A.; JENKIMSSMIT, H. C.; STEWARD JUNIOR, J. Toward better theories of the policy process (symposium). PS: Political Science and Politics, v. 24, n. 2, jun. 1991.

SECCHI, L. Políticas públicas: conceitos, esquemas de análise, casos práticos. São Paulo: Cengage Learning, 2010.

SEN, A. Desenvolvimento como liberdade. São Paulo: Companhia das letras, 2000. SILVA, P. L. B; MELO, M. A. B. O processo de implementação de políticas públicas no Brasil: características e determinantes de avaliação de programas e projetos. Cadernos de Pesquisa, NEPP, Unicamp, Campinas, n. 48, 2000.

SOARES, M. M.; MELO SOBRINHO, A. D.; Microfinanças: o papel do Banco Central do Brasil e a importância do cooperativismo de crédito. Brasília: BCB, 2008.

SOUZA, C. Políticas públicas: uma revisão da literatura. Sociologias, Porto Alegre, n. 16, p. 20-45, jul./dez. 2006.

THEODOULOU, S. Z. The contemporary language of public policy: a starting point. In: THEODOULOU, S. Z.; CAHN, M. A. Public policy: the essential readings. Upper Saddle River: Prentice Hall, 1995.

WEISS, C. H. The interface between evaluation and public policy. Evaluation, v. 5, n. 4, p. 468-486, 1999.

WEISSBOURD, R. Banking on technology: expanding financial markets and economic opportunity. Report for The Brookings Institution Center on Urban and Metropolitan Policy, jun. 2002.

YIN, R. K. Estudo de caso: planejamento e métodos. Porto Alegre: Bookman, 2005.

\section{Submissão: 10/03/2014}

Aprovação: 15/10/2014 
